\title{
臨老式死生観尺度を使用した実務実習を終えた 薬学生の死生観に関する意識調査
}

\author{
杉浦 宗敏 ${ }^{1,2)}$, 黒田誠一郎 ${ }^{2)}$, 海津未希子 ${ }^{3,4)}$, 中嶋須磨子 ${ }^{3)}$, \\ 岩瀬＼cjkstart哲占, 中島 由紀 ${ }^{1)}$, 内野 克喜 ${ }^{1)}$, 鈴木 洋史 ${ }^{2)}$
}

1) 東京薬科大学薬学部 医薬品安全管理学教室, 2) 東京大学医学部附属病院薬剤部, 3) 同 看護部,

4) 同 緩和ケア診療部, 5) 東京大学医科学研究所附属病院 緩和医療科

$$
\text { 受付日 } 2012 \text { 年 } 9 \text { 月 } 27 \text { 日/改訂日 } 2012 \text { 年 } 11 \text { 月 } 26 \text { 日/受理日 } 2012 \text { 年 } 12 \text { 月 } 11 \text { 日 }
$$

\begin{abstract}
【目的】緩和医療における薬剂師の積極的な関与が期待されており，薬学教育において死生観を形成するためのカリキュ ラム構築が重要である. 本研究は, その基礎的な情報収集として薬学生の死生観に対する意識を明らかにすることを目的と した.【方法】東京薬科大学薬学部の 2011 年度 6 年次生 159 名に平井ら (2000) の臨老式死生観尺度を使用して, 死生観 に対する意識を調査した. 家族, 近親者, 友人, ペットの死に立ち会った経験の有無で各因子スコアを比較し, 関連性をロジ スティック回帰分析により解析した.【結果・結論】対象学生の 120 名が有効な回答をした (有効回答率 $75.5 \%)$. 友人の死 に立ち会った経験がある学生は,「人生における目的意識」「死への関心」で有意に因子スコアが高かった $(p<0.05)$. 家族 などの死に立ち会った経験がある学生は,「死への関心」と正の相関が, 「死の恐怖・不安」と負の相関が有意に認められた $(p<0.05)$.

Palliat Care Res 2013; 8(2): 319-25
\end{abstract}

Key words: 臨老式死生観尺度, 薬学生, 死生観, 緩和医療教育

\section{緒 言}

2007 年にがん対策基本法が施行された. その施策の具体的 な行動計画となるがん対策推進基本計画には,がんと診断され た時からの緩和ケアの推進と, 緩和ケアを含むがん医療に携わ る専門的な医療従事者の育成が掲げられている ${ }^{1}$. 一方, 薬学教 育は 6 年制に移行し, 医療技術の高度化や医薬分業の進展など を背景に, 臨床において活躍できる高い資質をもつ薬剤師養成 を目指している2).

2002 年に改定された WHO (世界保健機関) の緩和医療の定 義では, 患者と家族の QOL を改善する方策として, 痛みのみ ならず身体的・心理的・スピリチュアルな諸問題に対する診 断, 治療による苦しみからの解放をその目標としている. した がって, 緩和医療における専門的な知識や技能を有した薬剤師 の育成には, 卒前卒後の体系的な教育がほとんど行われていな い現状では, 卒前の薬学教育で死生観を形成する場を提供する ためのカリキュラムの構築が重要である.

本研究では, その基礎的な情報収集のため, 薬学生の死生観 に対する意識を明らかにすることを目的とした。

\section{方 法}

1 調查対象・調查時期

「緩和医療の最前線」(選択科目) を履修した東京薬科大学薬
学部の 2011 年度 6 年次生 159 名を対象として, 死生観に関連 した内容の講義終了後の 2011 年 5 月に実施した. なお, 調査に 際して学生には書面による同意確認をした。

\section{2 調査内容}

調查内容は, 平井 $5^{3)}$ の臨老式死生観尺度 (Death Attiude Inventory; DAI) による「死後の世界観」「死への恐怖・不安」 「解放としての死」「死からの回避」「人生における目的意識」 「死への関心」「寿命観」の7つの因子による死生観に関する 計 27 の問いと家族, 近親者, 友人, ペットの死に立ち会った経 験の有無とした (表 1). なお, 死に立ち会った経験は複数回答 を可能とした.

死生観に対する問いはす心゙て「当てはまる」「かなり当ては まる」「やや当てはまる」「どちらともいえない」「やや当ては まらない」「ほとんど当てはまらない」「当てはまらない」の 7 件法とした.

\section{3 死に立ち会った経験とDAIの各因子スコア}

家族, 近親者, 友人, ペットの死に立ち会った経験についてそ れぞれある群とない群に分類し, DAI 各因子スコアの平均值を 算出した. 比較は, Mann-Whitney の U 検定を用いて, $p<0.05$ を 統計的に有意差があるとした。

また, 死に立ち会った経験の有無が死生観に関連性があるか 評価するために, 7 つ因子スコアを説明変数, いずれかの死

\footnotetext{
Corresponding author: 杉浦宗敏 | 東京薬科大学 薬学部・医薬品安全管理学教室

干 192-0392 東京都八王子市堀之内 1432-1

TEL·FAX 042-676-6622 E-mail: sugi-tky@umin.ac.jp
} 


\section{表 1 臨老式死生観尺度 ${ }^{3)}$}

\begin{tabular}{l}
\hline 【第 1 因子 死後の世界観】 \\
死後の世界はあると思う \\
世の中には「霊」や「たたり」があると思う \\
死んでも魂は残ると思う \\
人は死後, また生まれ変わると思う \\
\hline 【第 2 因子 死への恐怖・不安】 \\
死ぬことがこわい \\
自分が死ぬことを考えると, 不安になる \\
死は恐ろしいものだと思う \\
私は死を非常に恐れている \\
\hline
\end{tabular}

【第 3 因子 解放としての死】

私は, 死とはこの世の苦しみから解放されることだと 思っている

私は死をこの人生の重荷からの解放と思っている 死は痛みと苦しみからの解放である

死は魂の解放をもたらしてくれる

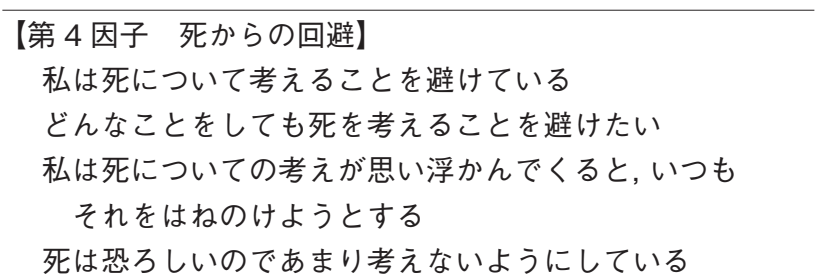

\section{【第 5 因子 人生における目的意識】}

私は人生にはっきりとした使命と目的を見出している 私は人生の意義, 目的, 使命を見出す能力が十分にある 私の人生について考えると, 今ここにこうして生きている 理由がはっきりしている

未来は明るい

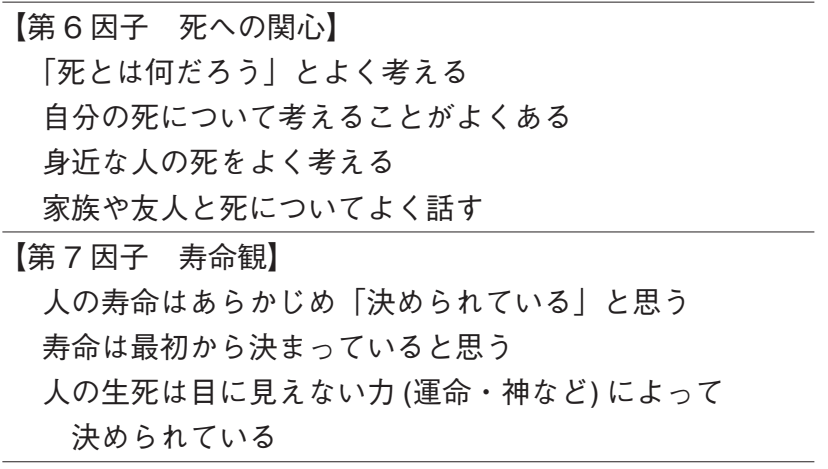

に立ち会った経験の有無を従属変数としてロジスティック回 帰分析を行った。

\section{結 果}

\section{1 薬学生の背景}

表 2 に調查対象とした薬学生の背景を示した. 対象とした 2011 年度東京薬科大学薬学部 6 年次生 159 名のうち, 120 名が 有効な回答をした (有効回答率 $75.5 \%$ ). 内訳は男性が 38 名 (31.6\%), 女性が 82 名 $(68.4 \%)$ だった.

今までに死に立ち会った経験があると回答した学生は, 家族 34 名 $(28.3 \%)$, 近親者 58 名 $(48.3 \%)$, 友人 15 名 $(12.5 \%)$, ペッ
表 2 薬学生の背景 $(n=120)$

\begin{tabular}{l|r}
\hline & 人数 (\%) \\
\hline 性別 & \\
男性 & $38(31.6)$ \\
女性 & $82(68.3)$ \\
\hline 死に立ち会った経験の有無 & \\
家族 & $34(28.3)$ \\
近親者 (親戚など) & $58(48.3)$ \\
友人 & $15(12.5)$ \\
ペット & $42(35.0)$ \\
その他 & $7(5.8)$ \\
なし (未回答) & $34(28.3)$ \\
\hline
\end{tabular}

ト 42 名 (35.0\%), その他 7 名 $(5.8 \%)$, 経験なし 34 名 $(28.3 \%)$ だった.

\section{2 死に立ち会った経験と DAI の各因子スコア}

表 3 に死に立ち会った経験の有無と DAI 各因子の平均スコ アを示した. 友人の死に立ち会った経験が有る群では,「人生に おける目的意識」 $(p=0.04)$ と「死への関心」 $(p=0.02)$ でスコ アが有意に高かった。

表 4 にいずれかの死に立ち会った経験と DAI 各因子スコア との関連性を示した.「死への関心」と正の相関 (オッズ比 1.68 , $p=0.01$ ) が,「死への恐怖・不安」と負の相関 (オッズ比 0.67 , $p=0.04)$ が有意に認められた.

\section{考 察}

死生観は宗教や人種などが大きく関係し,さらに個人的な体 験などが加味され形成するとされている ${ }^{4)}$. 今回の解析で使用 した DAI は, 日本人の死生観を測定するために作成され, 医学 生 ${ }^{5)}$ や看護学生 ${ }^{6)}$ の死生観を測定評価した研究などでも利用さ れている. 国内では薬学生の死生観を調查した報告はほとんど なく, 今回はその測定評価を実務実習で臨床現場を経験した 6 年次薬学生に対して行った.

薬学生全体の DAI 各因子の平均スコアは過去に報告 ${ }^{5,6)} さ$ れた座学後の医学生および座学後にエンゼルメイクの体験演 習を実施した看護学生と比較すると, それぞれ全 7 因子および 7 因子中 5 因子で高く同程度以上の結果が示された. 今回の調 查対象者が選択科目である「緩和医療の最前線」を履修した 学生であることや講義直後の調査であることから, 死生観に対 する態度が強く現れている可能性もあるが, 非常に興味深い結 果と考えられた.

先行研究では, 死に関するさまざまな体験や学習機会など, 自身の背景が死生観と関係がある可能性が指摘されている5 特に, 死生観形成には身近な人との死別体験が挙げられるが, 現代ではその体験が少ないと考えられる ${ }^{6}$. 今回の調查では, ペットを含めたいずれかの死に立ち会った経験のある学生は, 経験なしと回答した学生が $28.3 \%$ であることから $71.7 \%$ と換 算され，また複数経験者も $44.2 \%$ であった. これをそれぞれの 死に立ち会った経験の有無で層別分類して DAI 各因子の平均 スコアを比較した. 自身にとって最も身近な家族の死に立ち 会った経験のある学生は, 死生観に対寸る態度が強く現れると 
表 3 死に立ち会った経験の有無とDAI 各因子の平均スコア

\begin{tabular}{|c|c|c|c|c|c|c|c|c|c|c|c|c|c|}
\hline \multirow[b]{2}{*}{ 因子 } & \multicolumn{3}{|c|}{ 家族 } & \multicolumn{3}{|c|}{ 近親者 } & \multicolumn{3}{|c|}{ 友人 } & \multicolumn{3}{|c|}{ ペット } & \multirow{2}{*}{$\begin{array}{l}\text { 全体 } \\
(n=120\end{array}$} \\
\hline & $\begin{array}{c}\text { あり } \\
(\mathrm{n}=34)\end{array}$ & $\begin{array}{c}\text { なし } \\
(n=86)\end{array}$ & $p$ 值* & $\begin{array}{c}\text { あり } \\
(n=58)\end{array}$ & $\begin{array}{c}\text { なし } \\
(n=62)\end{array}$ & $p$ 值* & $\begin{array}{c}\text { あり } \\
(n=15)\end{array}$ & $\begin{array}{c}\text { なし } \\
(n=105)\end{array}$ & o 值 ${ }^{*}$ & $\begin{array}{c}\text { あり } \\
(n=42)\end{array}$ & $\begin{array}{c}\text { なし } \\
(n=78)\end{array}$ & $p$ 值* & \\
\hline 死後の世界観 & 3.43 & 3.70 & 0.50 & 3.74 & 3.52 & 0.48 & 4.22 & 3.54 & 0.21 & 3.69 & 3.59 & 0.63 & 3.63 \\
\hline 死への恐怖・不安 & 3.27 & 3.67 & 0.23 & 3.37 & 3.72 & 0.16 & 3.52 & 3.56 & 0.89 & 3.30 & 3.69 & 0.16 & 3.55 \\
\hline 解放としての死 & 2.88 & 2.98 & 0.48 & 3.03 & 2.88 & 0.81 & 3.55 & 2.87 & 0.38 & 3.16 & 2.84 & 0.65 & 2.95 \\
\hline 死からの回避 & 2.45 & 2.43 & 0.99 & 2.42 & 2.46 & 0.99 & 2.27 & 2.46 & 0.46 & 2.25 & 2.54 & 0.21 & 2.44 \\
\hline 人生における目的意識 & 3.91 & 4.19 & 0.38 & 4.11 & 4.11 & 0.89 & 4.78 & 4.01 & 0.04 & 4.19 & 4.07 & 0.86 & 4.11 \\
\hline 死への関心 & 4.01 & 4.02 & 0.76 & 4.11 & 3.93 & 0.49 & 4.87 & 3.90 & 0.02 & 4.30 & 3.86 & 0.09 & 4.02 \\
\hline 寿命観 & 3.05 & 3.01 & 0.98 & 3.07 & 2.98 & 0.71 & 3.44 & 2.96 & 0.19 & 3.27 & 2.89 & 0.30 & 3.02 \\
\hline
\end{tabular}

*Mann-Whitney $の \cup$ 検定

表 4 いずれかの死に立ち会った経験と DAI 各因子との関連性

\begin{tabular}{l|c|c|c}
\hline \multicolumn{1}{c|}{$\quad$ 因子 } & オッズ比 & $95 \% \mathrm{Cl}$ & $p$ 值 \\
\hline 死後の世界観 & 1.09 & $0.76 \sim 1.57$ & 0.65 \\
死への恐怖・不安 & 0.67 & $0.46 \sim 0.98$ & 0.04 \\
解放としての死 & 0.81 & $0.56 \sim 1.17$ & 0.26 \\
死からの回避 & 1.03 & $0.64 \sim 1.65$ & 0.92 \\
人生における目的意識 & 0.84 & $0.59 \sim 1.19$ & 0.33 \\
死への関心 & 1.68 & $1.15 \sim 2.45$ & 0.01 \\
寿命観 & 1.28 & $0.89 \sim 1.82$ & 0.18 \\
\hline
\end{tabular}

予想したが, 各スコアに有意な差は認められなかった. その理 由として自身にとって最も身近な家族との死別体験が, 死を現 実のものと捉えた時に死に対する不安や死について考えるこ とを拒否する傾向が表れ, 相殺された可能性も考えられた. し かし, 自身と対象者の関係や経験後の経過時間など詳細の調査 を今回は実施しておらず, その解析にはさらなる情報の収集が 必要と思われた. 一方, 友人の死に立ち会った経験がある群で は,「人生における目的意識」「死への関心」で有意にスコアが 高かった. 調查対象の学生はほとんどが 20 歳代前半であり, 同 年代の友人の死に立ち会う経験は非常に衝撃的な経験と推察 される.この経験が自己の生涯の時間的回想や自己肯定感を強 く促し,明確な差が示されたものと考えられた.

いずれかの死に立ち会った経験と DAI 各因子との関連性に ついての解析では,「死への関心」と正の相関が,「死の恐怖・ 不安」と負の相関が有意に認められた. 死に関するさまざまな 体験や学習機会が死生観に影響を与えるとの報告7 があるが, 今回の結果も種々の死別体験が死一の関心を高め, 死の恐怖 ・ 不安を軽減するきっかけとなり, 学生の死生観形成を促した可 能性を示唆するものと考えられた。

今回, 死生観に関連した内容の講義終了後に調査を行った が, 講義内容による学生の死生観形成に関寸る評価を行うこと はできなかった. 死生観形成に影響を与える学習形態には, 死 に関するグループ学習会の実施が有効とする報告 ${ }^{8}$ やロール プレイなど体験型学習が望ましいとする報告 ${ }^{4}$ がある. 本講義 は, 約 150 名の学生に対しておもに講師が講演する講義形式で あるが, 体験型の講義を組み込む工夫も効果的なカリキュラム の構築には必要と考えられた. 臨床現場で遭遇する患者の死は 他人の死である. 薬学教育が 6 年制に移行し, 臨床における実 務実習が必須となったが, 医学生や看護学生と比較すると患者
の死に遭遇する機会はまだ少ないことが予想される. Deeken ${ }^{9}$ は, 医療従事者が死に対する成熟した態度を身に付けるために は死への準備教育が必須であるとしている. 今後は, 今回の調 查結果を解析し, 他人の死にきちんと向き合う姿勢を身に付け るために死への準備教育となる卒前教育カリキュラム構築の 参考となることが望まれる.

以上から卒前の薬学教育において死生観を形成する場を提 供するための有効なカリキュラムを早急に構築し, 緩和医療に おいても医療チームの一員として活躍できる薬剤師を育成す ることが重要と考えられた.

\section{結 論}

薬学生の死生観に対する意識を明らかにすることを目的に, 平井ら ${ }^{3)}$ の DAI を使用して, 7 つの因子による死生観に対する 意識を調査した.

対象学生の 120 名が有効な回答をした (有効回答率 $75.5 \%$ ). 家族, 近親者, 友人,ペットの死に立ち会った経験の有無で各因 子スコアを比較し, 関連性をロジスティック回帰分析により解 析したところ, 家族などの死に立ち会った経験がある学生は, 「死一の関心」と正の相関が,「死の恐怖・不安」と負の相関が 有意に認められた $(p<0.05)$

\section{文 献}

1) 厚生労働省. がん対策推進基本計画. 2012 年 6 月〔http:// www.mhlw.go.jp/bunya/kenkou/d1/gan_keikaku02.pdf]

2) 文部科学省. 薬学教育改革. 2006 年 5 月〔http://warp.ndl.go. jp/info:ndljp/pid/286794/www.mext.go.jp/a_menu/01_d/ 08091815.htm] 
3) 平井 啓, 坂口幸弘, 安部幸志, 他. 死生観に関する研究一 死生観尺度の構成と信頼性 - 妥当性の検証. 死の臨 2000; 23: 71-6

4) 安達富美子. 日本人の死生観. 河野友信, 平山正実 編. 臨床 死生学事典. 日本評論社, 東京, 2000; 18-9.

5) 平川仁尚, 益田雄一郎, 葛谷雅文, 他. 終末期医療 - 看護に 関する授業と医学生の死生観との関係. 日老医誌 2007 ; 44: $247-50$.

6) 小林祐子, 和田由紀子, 若林理恵子, 他. ターミナルケア授 業にエンゼルメイク演習を取り入れた試み. ホスピスケア
在宅ケア 2010; 18:23-30.

7) 系島陽子. 死生観形成に関する調查一看護学生と大学生の 比較. 京都看短大紀 $2005 ; 30: 141-7$.

8) 平川仁尚, 葛谷雅文, 加藤利章, 他. 高齢者ケアに関わる職 員を対象とした絵本を用いた死の教育の効果. ホスピスケ ア在宅ケア 2009; 17: 14-6.

9) Alfons Deeken. 死への準備教育 第 1 巻一死を教える. メヂ カルフレンド社, 東京, 1998; 48-58.

著者の申告すべき利益相反なし 


\title{
Short Communication
}

\section{A survey of the death attitude of pharmacy students finished clinical training using the Death Attitude Inventory}

\author{
Munetoshi Sugiura $^{1,2)}$, Seiichiro Kuroda ${ }^{2)}$, Mikiko Kaitsu ${ }^{3,4)}$, Sumako Nakajima ${ }^{3)}$, \\ Satoru Iwase ${ }^{5)}$, Yuki Nakajima ${ }^{1)}$, Katsuyoshi Uchino ${ }^{1)}$ and Hiroshi Suzuki ${ }^{2)}$
}

\begin{abstract}
1) Department of Drug Safe Management, School of Pharmacy, Tokyo University of Pharmacy and Life Sciences, 2) Department of Pharmacy, The University of Tokyo Hospital, Faculty of Medicine, The University of Tokyo, 3) Department of Nursing, ditto, 4) Department of Palliative Medicine, ditto, 5) Department of Palliative Medicine, Research Hospital, The Institute of Medical Science, The University of Tokyo
\end{abstract}

\begin{abstract}
Purpose: Pharmacists should play a positive role in palliative care. The pharmacy curriculum should also contain content promoting an appropriate attitude toward death. Hence, this study aims to gather fundamental information that can be used to understand the various death attitudes held by pharmacy students. Methods: We targeted 159 sixthyear students of the School of Pharmacy, Tokyo University of Pharmacy and Life Sciences, in 2011. They studied "Upto-date-Palliative-Care" (an elective subject). To investigate their overall perception of death, we used the Death Attitude Inventory (DAI), developed by Hirai and others (2000), and investigated their views of death on the basis of seven factors. We also classified students on the basis of type of death they had experienced, that is, the death of a household, relative, friend, or pet. We compared the scores obtained for each factor and conducted a logistic regression analysis. Results and Conclusion: We analyzed the data from 120 students (valid response rate: $75.5 \%$ ). Students who had experienced the death of friend, had significantly higher scores on "Life Purpose" and "Death Concern" $(p<0.05)$. Students who had experienced the death of household etc., statistical positive correlation with "Death Concern" and statistical negative correlation with "Death Anxiety" were recognized. Palliat Care Res 2013; 8(2): 319-25
\end{abstract}

Key words: Death Attitude Inventory, pharmacy students, death attitude, education of palliative care 
Table 1 Death Attitude Inventory
【1. Afterlife belief】
I think that there is the next world
I think that there are "soul" and "curse" in this world
I think that a soul remains although dies
People are supposes as a postmortem and an again birth vary

\title{
【2. Death anxiety】 \\ Dying is dreadful \\ I think that I turn uneasy about dying \\ I think that death is a terrifying thing \\ I fear death very much
}

\section{【3. Death relief】}

I think that death is released from pain in this world

I regard death as the relief from the pressure of this life

Death is in pain with a pain and is a relief of a valve

Death brings about a spiritual relief

\author{
【4. Death avoidance】 \\ I avoid considering death \\ No matter what it may carry out, I would like to avoid considering death \\ I am going to eliminate it, whenever the view about death occurs \\ I am trying to seldom consider death by that of a terrifying
}

\section{【5. Life purpose】}

I have found out the mission and the purpose which were clearly made into life

For me, the power to find out the significance of life, the purpose, and a mission is an exist to a sufficiently The reason for an alive has clarified in this way now with the consider about my life here

The future is bright

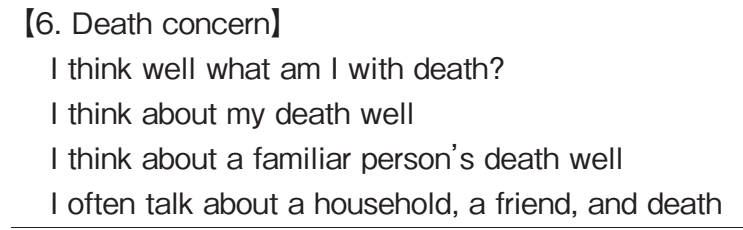

【7. Supernatural belief】

People's span of life considers beforehand "I am decided by it"

A span of life is a suppose as having been decided from the original

People's life and death are decided by the power (a fate, God, etc.) which is not a foregone conclusion 
Table 2 Background of pharmacy students $(n=120)$

\begin{tabular}{l|c}
\hline & $\begin{array}{c}\text { Number of } \\
\text { students (\%) }\end{array}$ \\
\hline Sex & $38(31.6)$ \\
Male & $82(68.3)$ \\
Female & \\
\hline Experienced the death & $34(28.3)$ \\
Household & $58(48.3)$ \\
Relative & $15(12.5)$ \\
Friend & $42(35.0)$ \\
Pet & $7(5.8)$ \\
Others & $34(28.3)$ \\
Nothing (non response) &
\end{tabular}

Table 3 Experience the death and mean score of DAl's factors

\begin{tabular}{|c|c|c|c|c|c|c|c|c|c|c|c|c|c|}
\hline \multirow[b]{2}{*}{ Factor } & \multicolumn{3}{|c|}{ Household } & \multicolumn{3}{|c|}{ Relative } & \multicolumn{3}{|c|}{ Friend } & \multicolumn{3}{|c|}{ Pet } & \multirow{2}{*}{$\begin{array}{c}\text { All } \\
(n=120)\end{array}$} \\
\hline & $\begin{array}{c}\text { Yes } \\
(n=34)\end{array}$ & $\begin{array}{c}\text { No } \\
(n=86)\end{array}$ & $p^{*}$ & $\begin{array}{c}\text { Yes } \\
(n=58)\end{array}$ & $\begin{array}{c}\text { No } \\
(n=62)\end{array}$ & $p^{*}$ & $\begin{array}{c}\text { Yes } \\
(n=15)\end{array}$ & $\begin{array}{c}\text { No } \\
(n=105)\end{array}$ & $p^{*}$ & $\begin{array}{c}\text { Yes } \\
(n=42)\end{array}$ & $\begin{array}{c}\text { No } \\
(n=78)\end{array}$ & $p^{*}$ & \\
\hline Afterlife belief & 3.43 & 3.70 & 0.50 & 3.74 & 3.52 & 0.48 & 4.22 & 3.54 & 0.21 & 3.69 & 3.59 & 0.63 & 3.63 \\
\hline Death anxiety & 3.27 & 3.67 & 0.23 & 3.37 & 3.72 & 0.16 & 3.52 & 3.56 & 0.89 & 3.30 & 3.69 & 0.16 & 3.55 \\
\hline Death relief & 2.88 & 2.98 & 0.48 & 3.03 & 2.88 & 0.81 & 3.55 & 2.87 & 0.38 & 3.16 & 2.84 & 0.65 & 2.95 \\
\hline Death avoidance & 2.45 & 2.43 & 0.99 & 2.42 & 2.46 & 0.99 & 2.27 & 2.46 & 0.46 & 2.25 & 2.54 & 0.21 & 2.44 \\
\hline Life purpose & 3.91 & 4.19 & 0.38 & 4.11 & 4.11 & 0.89 & 4.78 & 4.01 & 0.04 & 4.19 & 4.07 & 0.86 & 4.11 \\
\hline Death concern & 4.01 & 4.02 & 0.76 & 4.11 & 3.93 & 0.49 & 4.87 & 3.90 & 0.02 & 4.30 & 3.86 & 0.09 & 4.02 \\
\hline Supernatural belief & 3.05 & 3.01 & 0.98 & 3.07 & 2.98 & 0.71 & 3.44 & 2.96 & 0.19 & 3.27 & 2.89 & 0.30 & 3.02 \\
\hline
\end{tabular}

Table 4 Relationship to experience the death and DAl's factors

\begin{tabular}{l|c|c|c}
\hline \multicolumn{1}{c|}{ Factor } & Ods & $95 \% \mathrm{Cl}$ & $p^{*}$ \\
\hline Afterlife belief & 1.09 & $0.76 \sim 1.57$ & 0.65 \\
Death anxiety & 0.67 & $0.46 \sim 0.98$ & 0.04 \\
Death relief & 0.81 & $0.56 \sim 1.17$ & 0.26 \\
Death avoidance & 1.03 & $0.64 \sim 1.65$ & 0.92 \\
Life purpose & 0.84 & $0.59 \sim 1.19$ & 0.33 \\
Death concern & 1.68 & $1.15 \sim 2.45$ & 0.01 \\
Supernatural belief & 1.28 & $0.89 \sim 1.82$ & 0.18 \\
\hline
\end{tabular}

